\title{
REDUCTION OF NITRITES ADDITION IN COOKED SAUSAGES FROM PHYTONUTRIENT SUPPLEMENTED PORK
}

\author{
Desislava Borislavova Vlahova-Vangelova ${ }^{1 凶}$, Desislav Kostadinov Balev ${ }^{1}$, \\ Stefan Georgiev Dragoev ${ }^{1}$, Rada Hristova Dinkova ${ }^{2}$ \\ ${ }^{I}$ Department of Meat and Fish Technology, Technological Faculty, University of Food Technologies, \\ Plovdiv, Bulgaria \\ ${ }^{2}$ Department of Food Preservation and Refrigeration Technology, Technological Faculty, University of Food \\ Technologies, Plovdiv, Bulgaria \\ ${ }^{\bowtie}$ desislava_vangelova@abv.bg \\ https://doi.org/10.34302/crpjfst/2020.12.4.7 \\ Article history: \\ Received: \\ 17 September 2020 \\ Accepted: \\ 17 December 2020 \\ Keywords: \\ Dihydroquercetin; \\ Dry distilled rose petals; \\ Pig's feed; \\ Sensory properties; \\ TBARS.

\section{ABSTRACT} \\ The aim of this study was to develop functional cooked sausages with \\ reduced nitrites addition manufactured using pork after daily \\ supplementation with 3.5 and $7.5 \mathrm{mg}$ dihydroquercetin (DHQ) (samples \\ $\mathrm{D} 1$ and D2, respectively) or 0.255 and $0.545 \mathrm{~g}$ dry distilled rose petals \\ (Rosa damascene Mill.) (DDRP) (samples R1 and R2, respectively)/kg live \\ weight/d. The sensory properties, colour characteristics $\left(L^{*}, a^{*}, b^{*}\right)$, \\ TBARS and shelf life of the sausages were studied. Lower concentration of \\ used phytonutrients approve sensory acceptance of sausages with half \\ added nitrites. Higher doses of DHQ and DDRP supplements increased the \\ sausage $\mathrm{pH}$ by $3 \%(\mathrm{p}<0.05)$. The use of $0.545 \mathrm{~g}$ DDRP $/ \mathrm{kg}$ live weight $/ \mathrm{d}$ \\ as a feed supplement decreased the $\mathrm{L}^{*}$ value and increased the redness $\left(\mathrm{a}^{*}\right)$ \\ in processed sausages while the higher doses of DHQ show an opposite \\ effect. Feed enrichment with DHQ or DDRP is appropriate for \\ manufacturing functional sausages with half added nitrites addition due to \\ the stabilizing effect on colour $\left(L^{*}, a^{*}, b^{*}\right)$ characteristics in dynamics, the \\ decreasing of TBARS and the increasing of the sausages shelf life.
}

\section{Introduction}

In recent years the development of novel functional foods has been focused on food industry. The increasing consumer health-care pays attention to the use of ingredients with proven anticancer, anti-mutagenic, antioxidant and delaying degenerative effect preventing the number of diseases in modern society (Kumar et al., 2015). The first approach to creating functional meat products is the addition of natural supplements with a healthy effect such as vegetables, proteins, antioxidants, probiotics and prebiotics, soybeans, fruits, lactic acid bacteria etc. during manufacturing (Todra and Reig, 2011). Many consumers preferred meat products without allergens formulated by eliminating of the ingredients causing different types of allergies (Arihara, 2006).

Using the second approach, the composition of meat products can also be improved by animal feed enrichment. Feed supplement with conjugated linoleic acid impact on the accumulation of fatty acids and increase the nutritional value of the meat (Terpstra et al., 2002). The feed enrichment with vitamin $\mathrm{E}$ inhibits the protein and lipid oxidation and improves the color stability (Cardinali et al., 2015). Linseed and rapeseed oil increased the long-chain PUFAs in meat (Lopez-Ferrer et al., 2001) and the addition of selenium is proven to increased its intramuscular content by $66 \%$ (Jiang and Xiong, 2016). Algae also have been used to 
improve the nutritional value of feed (Christaki et al., 2010).

The use of herbs and spices like oregano (Origanum vulgare L.), rosemary (Rosmarinus officinalis L.) as well as sage (Salvia officinalis L.) shows a high antioxidant capacity (Cardinali et al., 2015; Jiang and Xiong, 2016) and increases products shelf life.

Dihydroquercetin (DHQ) from Siberian larch (Larix sibirica Ledeb) is a natural antioxidant with proven antioxidant properties. DHQ inhibits the oxidation of LDL-cholesterol in blood serum (Artem'eva et al., 2015).

The distilled rose petals are an interesting by-product, a waste material in rose oil and rose water production (Rosa Damascena Mill.). It is a typical Bulgarian raw material containing a wide range of antioxidant components flavonoids with synergistic, antioxidative and antibacterial effect (Shikov et al., 2012). According to Balev et al. (2015) the broiler feed supplemented with dry rose petals improves feed conversion.

In order to produce healthy meat products attempts have been made to reduce the nitrites during cooked sausages manufacturing (Vlahova-Vangelova et al., 2014).

The production of meat with functional properties by a modeled chemical composition and an increase in the nutritional value after feed supplementing (Nieto et al., 2010) is a challenge and innovation. The sausages manufactured with supplemented meat may have potential functional properties. Therefore, the purpose of this study was to develop a new strategy for processing of functional cooked sausages with half added nitrites manufactured by using pork obtained from pigs fed with supplements of 3.5 and $7.5 \mathrm{mg}$ DHQ or 0.255 and $0.545 \mathrm{~g} \mathrm{DDRP} / \mathrm{kg}$ live weight/ $\mathrm{d}$.

\section{Materials and methods}

\subsection{Feed supplements}

The dihydroquercetin powder (96\%) from Siberian larch (Larix sibirica Ledeb) was provided by Flavitlife Bio JSCo (Sofia, Bulgaria). Distilled rose petals were supplied by Bulattars Production Company Ltd (Sofia, Bulgaria), Pavel Banya, Stara Zagora district.
The by-product after the rose oil distillation was pressed dried $\left(60^{\circ} \mathrm{C}, 6 \mathrm{~h}\right)$ and ground $(<$ $0.4 \mathrm{~mm})$.

\subsection{Animal feeding, supplementation and harversting}

The pigs (Danube white breed) were bred on the State Enterprise Experimental Farm at Agricultural Institute; Shumen, Bulgaria divided into five groups (one control and four experimental) each comprised of 8 animals. The animals received a typical commercial diet - libitum grower diet up to $60 \mathrm{~kg}$ live weight and a finisher up to $110 \mathrm{~kg}$. After 155 day at an average live weight of $72 \mathrm{~kg}$ the pigs diets were supplemented for the last 40 days as follows: control (C) commercial diet without any supplement; sample D1 - commercial diet with $3.5 \mathrm{mg} \mathrm{DHQ} / \mathrm{kg}$ live weight/d supplement; sample D2 - commercial diet with $7.5 \mathrm{mg}$ $\mathrm{DHQ} / \mathrm{kg}$ live weight/d supplement; sample R1 commercial diet with $0.255 \mathrm{~g}$ DDRP $/ \mathrm{kg}$ live weight/d supplement; sample R2 - commercial diet with or $0.545 \mathrm{~g} \mathrm{DDRP} / \mathrm{kg}$ live weight $/ \mathrm{d}$ supplement.

After 40 days of supplemental feeding the pigs were transported and harvested at a processing plant (Unitemp Ltd., Voyvodinovo village, Plovdiv district, Bulgaria) in accordance with Council Regulations (EC) No $1 / 2005$.

After $24 \mathrm{~h}$ chilling at $4^{\circ} \mathrm{C}$ each carcass was quartered at 12-13 rib, deboned and cold stored at $2 \pm 1{ }^{\circ} \mathrm{C}$. The chilled $(48 \mathrm{~h})$ to $0 \pm 4^{\circ} \mathrm{C}$ pork rump $(\mathrm{pH}$ 6.40) and pork chest $(\mathrm{pH} 6.5)$ were used for sausage production.

\subsection{Sausage manufacturing}

The sausages were produced in accordance with the requirements of the cooked meat product appropriate for EU (Table 1). Pork rump and pork chest obtained from five animal groups (C, D1, D2, R1, R2) were separately cut into pieces and used for the production of six sausage samples. Each filling mass was manufactured by mixing with salt and phosphates and blended in a cutter with an addition of flake ice. During sausages manufacturing the nitrites for experimental 
groups D1, D2, R1, R2 were added in half. Pork rumps and pork chests from control group (C) were used for the production of two control samples: control C - with $100 \%$ nitrite addition and control sample $\mathrm{C}^{1 / 2}$ - with half-added nitrites. After filling in moisture and gases nopermeable five-layer polymer casings the sausages were cooked to an internal temperature of $72^{\circ} \mathrm{C}$ and chilled in cold water. The examinations were made dynamically on 1 and 7 day of the sausage refrigerated storage at $0- \pm 4^{\circ} \mathrm{C}$.

The sodium chloride (salt), sugar and sodium nitrite (E250) were provided from the local market.

\subsection{Methods}

\subsubsection{Sensory analysis}

The sensory properties (cross sectional view, flavor, taste, color, texture) of the sausages were determined with a panel consisting of five members with proven tasting abilities (Meilgaard et al., 1999). The samples were scored using 1 to 5 scales.

\subsubsection{Colour characteristics}

The color properties CIE L*, a*, b* (Hunt et al., 2012) of the sausages on 1st day of storage at $0 \pm 4^{\circ} \mathrm{C}$ were determined with Colorimeter Konica Minolta model CR-410 (Konica Minolta Holding, Inc., Ewing, USA), purchased by Sending, Inc. (Tokyo, Japan).

The changes of the color properties in the dynamics of the sausage surface cross-sectional views during the $60 \mathrm{~min}$ air exposure were examined on the 1 st day of storage.

Table 1. Formulation of different samples functional cooked sausages

\begin{tabular}{|c|c|c|c|c|c|c|}
\hline \multicolumn{7}{|c|}{ Samples } \\
\hline & $\mathbf{C}$ & $\mathrm{C}^{1} / 2$ & D1 & D2 & R1 & $\mathbf{R 2}$ \\
\hline $\begin{array}{l}\text { Feed } \\
\text { supplementation }\end{array}$ & $\begin{array}{c}\text { No } \\
\text { suppl. }\end{array}$ & $\begin{array}{c}\text { No } \\
\text { suppl. }\end{array}$ & $\begin{array}{c}3.5 \mathrm{mg} \mathrm{DHQ} / \\
\mathrm{kg} \text { live } \\
\text { weight/ d }\end{array}$ & $\begin{array}{c}7.5 \mathrm{mg} \text { DHQ/ } \\
\mathrm{kg} \text { live weight/ } \\
\mathrm{d}\end{array}$ & $\begin{array}{c}0.255 \text { g DDRP/ } \\
\text { kg live weight } / \\
\mathrm{d}\end{array}$ & $\begin{array}{c}0.545 \mathrm{~g} \\
\text { DDRP/ kg live } \\
\text { weight } / \mathrm{d}\end{array}$ \\
\hline \multicolumn{7}{|c|}{ Sausage ingredients } \\
\hline Pork rump, $\mathrm{g} / \mathrm{kg}$ & 500 & 500 & 500 & 500 & 500 & 500 \\
\hline Pork chest, $\mathrm{g} / \mathrm{kg}$ & 500 & 500 & 500 & 500 & 200 & 200 \\
\hline Flake ice, $\mathrm{g} / \mathrm{kg}$ & 200 & 200 & 200 & 200 & 200 & 200 \\
\hline $\begin{array}{l}\text { Sodium chloride, } \\
\mathrm{g} / \mathrm{kg}\end{array}$ & 20 & 20 & 20 & 20 & 20 & 20 \\
\hline $\begin{array}{l}\text { Polyphosphates, } \\
\text { g/kg }\end{array}$ & 2 & 2 & 2 & 2 & 2 & 2 \\
\hline $\begin{array}{l}\text { Sodium nitrite, } \\
\mathrm{g} / \mathrm{kg}\end{array}$ & 0.10 & 0.05 & 0.05 & 0.05 & 0.05 & 0.05 \\
\hline
\end{tabular}

\subsection{3. $\mathrm{pH}$ value}

The $\mathrm{pH}$ value of the samples was determined by $\mathrm{pH}$-meter MS 2004, $\mathrm{pH}$ combination recorder S $450 \mathrm{CD}$ (Sensorex $\mathrm{pH}$ Electrode Station, USA) (Young et al., 2004).

2.4.4. 2-Thiobarbituric acid reactive substances (TBARS)

The double beam UV-VIS spectrophotometer M550 (Camspec Ltd,
Cambridge, UK) was used for determination of the secondary products of the lipid oxidation expressed by malondialdehyde content (Botsoglou et al., 1994).

\subsubsection{Microbiological assay}

The samples for the microbiological assay were prepared by tenfold logarithmic dilution after homogenization with $90 \mathrm{~mL}$ of $0.85 \%$ sodium chloride for 2 min at 200 min-1 (Merck 
Bulgaria Joint-stock company, Sofia, Bulgaria) in stomacher bags (Seward Ltd, Worthing, West Sussex, UK). Once diluted, $1 \mathrm{~cm}^{3}$ of the sample was added to sterile Petri plates (in triplicate for each dilution) with cooled to $45^{\circ} \mathrm{C}$ suitable agar (Sharma et al., 2005). The total viable count (TVC) was determined after $72 \mathrm{~h}$ incubation at $28^{\circ} \mathrm{C}$ on a plate count agar (PCA, Merck Bulgaria Joint-stock company, Sofia, Bulgaria) following the ISO 4833:2003 procedure and the count of yeast - after incubation of the same type on potato-dextrose agar Merck 1.10130 (Merck Bulgaria Jointstock company, Sofia, Bulgaria) (Gelabert et al., 2003).

\subsubsection{Statistical analysis}

Statistical analysis of the average values of five time reps was made. All statistical procedures for the data of different samples were analyzed by SAS software (SAS Institute, Inc. 1990). The Student-Newman-Keuls multiple range test was used to compare differences among means. The results were expressed as mean values and standard errors of the mean. A p-value less than $0.05(\mathrm{p}<0.05)$ was considered as significant.

\section{Results and discussions}

\section{1. $\mathrm{pH}$ value}

$\mathrm{pH}$ in control sample $\mathrm{C}$ (Table 2), $\mathrm{C}^{1 / 2}$, as well as samples D1 does not differ significantly $(p>0.05)$. On the contrary, sausages from samples D2 and R2 had 3\% higher $\mathrm{pH}(\mathrm{p}<$ $0.05)$. For both used feed antioxidants the higher daily dose (7.5 mg DHQ $/ \mathrm{kg}$ live weight $/ \mathrm{d}$ or $0.545 \mathrm{~g} / \mathrm{kg}$ DDRP/live weight/d increased the $\mathrm{pH}$ in sausages with half added nitrites. The results confirmed previous research that the feed supplements not only change the meat $\mathrm{pH}$ (Wiklund et al., 2001) but also influence the $\mathrm{pH}$ of the manufactured sausages.

\subsection{Sensory evaluation}

The highest scores for cross sectional view and color were identified in samples C, $\mathrm{C}^{1 / 2}$ and the sausages from sample D1. The sensory panel confirmed the best flavor and taste in sausages from sample D1 followed by those from sample $\mathrm{R} 1$ and sample $\mathrm{C} 1 / 2$ (Fig. 1).

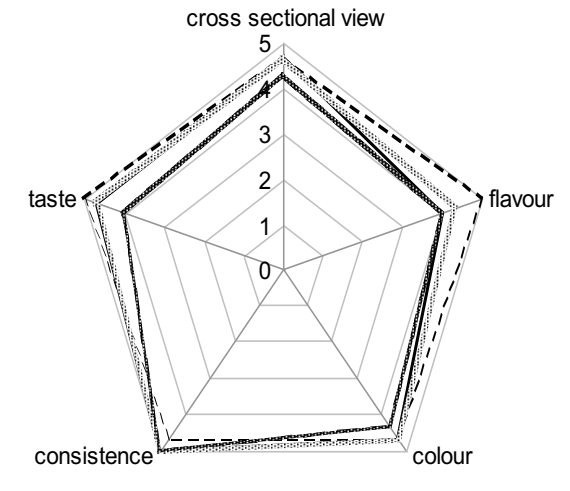

Figure 1. Sensory properties of studied sausages

The lowest flavor scores were obtained for sausages from samples D2 and R2. As many researchers exploring the effect of feed enriching on meat quality (Jerónimo et al., 2009; Sobolev et al., 2017) we can confirm that the concentration of the feed supplements is a very important factor for the sensory quality of pork functional sausages. It is clear that lower doses of DHQ in sample D1 and DDRP added in sample R1 had the positive effect on sensory acceptance of the produced sausages with half added nitrites (Fig. 1).

\subsection{Colour characteristics $\left(L^{*}, a^{*}, b^{*}\right)$}

On the first day of storage $\left(0 \pm 4^{\circ} \mathrm{C}\right)$ the highest color lightness $\mathrm{L}^{*}$ (Table 2) was established in sausages from sample D2 (p < $0.05)$. On the contrary, the lowest $L^{*}$ value $(p<$ 0.05 ) was found in sausages from sample R2.

Closest to the control sample with $100 \%$ nitrites (C) was the colour lightness ( $\left.\mathrm{L}^{*}\right)$ in sausages D1, while $\mathrm{L}^{*}$ value in sample D2 was $2.3 \%$ higher $(p<0.05)$. Both the type and the concentration of supplements (DHQ or DDRP) durind pigs' feeding affect the colour lightness $\mathrm{L}^{*}$ in produces sausages.

While higher doses of DDRP supplement reduced the $\mathrm{L}^{*}$ value in sausages from sample $\mathrm{R} 2$, in D2 the $\mathrm{L}^{*}$ value increased by $2.3 \%(\mathrm{p}<$ 0.05 ) compared to C. Previous experiments with addition of rose petal extract in filling mass during sausages manufacturing, confirmed decrease in $\mathrm{L}^{*}$ value of cut surface 
compared to the $100 \%$ nitrite control sample, too (Vlahova-Vangelova et al., 2014).

Obviously, both the use of DDRP as feed supplement with subsequent sausage manufacturing and DDRP addition during sausage processing decreased the colour lightness $\mathrm{L}^{*}$ in the produced sausages with half added nitrites.

Table 2. Changes in $\mathrm{pH}$, colour $\left(\mathrm{L}^{*}, \mathrm{a}^{*}, \mathrm{~b}^{*}\right)$ characteristics, TBARS and microflora of studied sausage samples

\begin{tabular}{|c|c|c|c|c|c|c|c|}
\hline & & \multicolumn{6}{|c|}{ Samples } \\
\hline & $\begin{array}{l}\text { Day of } \\
\text { storage }\end{array}$ & $\mathbf{C}$ & $\mathrm{C}^{1} / 2$ & D1 & D2 & $\mathbf{R} 1$ & $\mathbf{R} 2$ \\
\hline $\mathrm{pH}$ & 1 & $6,50^{\mathrm{a}} \pm 0,05$ & $6,50^{\mathrm{a}} \pm 0,05$ & $6,50^{\mathrm{a}} \pm 0,05$ & $6,70^{\mathrm{b}} \pm 0,05$ & $6,60^{\mathrm{a}, \mathrm{b}} \pm 0,05$ & $6,70^{\mathrm{b}} \pm 0,05$ \\
\hline $\mathrm{L}^{*}$ & 1 & $59,57^{\mathrm{a}} \pm 0,04$ & $58,97^{\mathrm{b}} \pm 0,06$ & $59,19^{c} \pm 0,03$ & $61,12^{\mathrm{e}} \pm 0,04$ & $60,74^{d} \pm 0,12$ & $58,43^{a} \pm 0,12$ \\
\hline$a^{*}$ & 1 & $11,76^{\mathrm{b}} \pm 0,03$ & $12,70^{\mathrm{d}} \pm 0,59$ & $12,39^{\mathrm{c}} \pm 0,04$ & $11,22^{\mathrm{a}} \pm 0,01$ & $11,25^{\mathrm{a}} \pm 0,06$ & $12,80^{\mathrm{d}} \pm 0,02$ \\
\hline $\mathrm{b}^{*}$ & 1 & $6,72^{d} \pm 0,06$ & $5,32^{\mathrm{a}} \pm 0,05$ & $5,77^{\mathrm{b}} \pm 0,04$ & $6,98^{\mathrm{e}} \pm 0,01$ & $6,17^{\mathrm{c}} \pm 0,02$ & $6,18^{c} \pm 0,12$ \\
\hline $\begin{array}{l}\text { TBARS, } \\
\text { mgMDA/kg }\end{array}$ & 1 & $0,41^{\mathrm{a}} \pm 0,02$ & $0,53^{b} \pm 0,03$ & $0,58^{\mathrm{b}} \pm 0,02$ & $0,54^{\mathrm{b}} \pm 0,04$ & $0,46^{\mathrm{a}} \pm 0,03$ & $0,42^{\mathrm{a}} \pm 0,04$ \\
\hline $\begin{array}{l}\text { TBARS, } \\
\mathrm{mgMDA} / \mathrm{kg}\end{array}$ & 7 & $0,43^{\mathrm{a}} \pm 0,04$ & $0,75^{\mathrm{c}} \pm 0,07$ & $0,67^{\mathrm{c}} \pm 0,05$ & $0,56^{\mathrm{b}} \pm 0,04$ & $0,51^{\mathrm{a}, \mathrm{b}} \pm 0,06$ & $0,68^{\mathrm{c}} \pm 0,09$ \\
\hline $\begin{array}{l}\text { TVC, } \\
\log \mathrm{cfu} / \mathrm{g}\end{array}$ & 7 & $4,00^{\mathrm{a}} \pm 0,20$ & $4,70^{\mathrm{b}} \pm 0,10$ & $4,30^{\mathrm{a}}{ } \pm 0,15$ & $4,30^{\mathrm{a}} \pm 0,20$ & $4,00^{\mathrm{a}} \pm 0,12$ & $4,30^{\mathrm{a}} \pm 0,10$ \\
\hline $\begin{array}{l}\text { Yeasts and } \\
\text { molds, } \\
\log \mathrm{cfu} / \mathrm{g}\end{array}$ & 7 & $4,00^{\mathrm{a}} \pm 0,25$ & $5,00^{\mathrm{b}} \pm 0,20$ & $4,54^{\mathrm{a}} \pm 0,30$ & $4,81^{\mathrm{a}, \mathrm{b}} \pm 0,15$ & $4,54^{\mathrm{a}} \pm 0,30$ & $4,70^{\mathrm{a}, \mathrm{b}} \pm 0,10$ \\
\hline
\end{tabular}

a, b,c Means in the same row with different superscript letters differ significantly $(\mathrm{p}<0.05)$.

SEM- standard error of the mean.

Similar effect on the colour lightness $\left(\mathrm{L}^{*}\right)$ was reported by Salejda et al. (2017) exploring sausages manufactured with addition of powder sea buckthorn.

Compared to the sample C (Table 2) sausages with a higher dose of DHQ enriched meat (D2) as well as a lower supplement of DDRP (sample R1) had lower colour redness (a *) $(\mathrm{p}<0.05)$.

On the contrary, in D1 and R2 sausages the $\mathrm{a}^{*}$ value was found higher. Comparing the six studied samples (C, C1/2, D1, D2, R1,

R2) a* values in D2 and R1 samples were closest to controls $\mathrm{C}$ (with 100\% nitrites addition) (Table 2). The conclusion was made that two used phytonutrients had different impact on the colour redness $\mathrm{a}^{*}$. The increase of DHQ concentration as supplement decreased the $\mathrm{a}^{*}$ value, while the samples from meat enriched with higher concentration of DDRP (R2) significantly increased colour redness ( $\left.a^{*}\right)$ with $8.84 \%$ in pork cooked sausages. It seems that the type of used supplement as well as his concentration had the different impact on sausage colour characteristics. For example, Fernández-López et al. (2005) confirm the increasing of colour redness $\left(\mathrm{a}^{*}\right)$ in beef meatballs manufacturing after addition of rosemary, garlic, orange, and lemon extracts. Contrary, Salejda et al. (2017) reported for reduction of colour lightness $\left(\mathrm{L}^{*}\right)$ and redness $\left(a^{*}\right)$ after sausage processing with sea buckthorn. Even more, the authors (Salejda et al., 2017) found negative effect on sausage colour acceptance with the increasing of sea buckthorn concentration.

On the first day of storage $\left(0 \pm 4^{\circ} \mathrm{C}\right)$ the lowest $b^{*}$ value (of colour yellowness) was found on the cut surface of the sausages from sample $\mathrm{C}^{1} \frac{1}{2}$ followed by samples D1, R1 and R2. Compared to control sample C (with 100\% nitrites addition) the established decrease $(\mathrm{p}<$ 0.05 ) was $26 \%, \quad 16.5 \%, 8.7 \%$ and $8.7 \%$ 
respectively (Table 2 ). A decrease in the $b *$ value after addition of rose petal extract during the sausages processing had been found previously by Vlahova-Vangelova et al. (2014), too. In sausages D2 and R1 processed with half added nitrites yellow color component $\mathrm{b} *$ was found to be closest to $\mathrm{C}$.

\subsection{TBARS}

On the first day of the sausage storage $(0 \pm$ $4^{\circ} \mathrm{C}$ ) the lowest TBARS (Table 2 ) was found in the controls $\mathrm{C}$ followed by sausages from DDRP enriched meat with half added nitrites (samples R1 and R2) ( $p>0.05)$. Our results are in agreement with Karwowska and Dolatowski (2013) findings considered that the addition of mustard seed improve oxidation stability in pork sausages.

In comparison to $\mathrm{C}$, after 7 days of storage $\left(0 \pm 4^{\circ} \mathrm{C}\right)$ sample $\mathrm{C}^{1 / 2}$ had two times higher content of TBARS $(p<0.05)$. The significant oxidative stability in lipid fraction was found in control $\mathrm{C}$ as well as in D2 and R1 sausages (Table 2). For the mentioned two samples TBARS does not change significantly $(\mathrm{p}>$ $0.05)$ for the seven-day storage period $(0 \pm$ $\left.4^{\circ} \mathrm{C}\right)$.

Similar to our results were reported after oregano, rosemary, vitamin E (Cardinali et al., 2015), oleic acid and tocopherol (Ventanas et al., 2007) as well as natural phenolic antioxidants (Jiang and Xiong, 2016) feed supplementation. We can conclude that feed supplement with DHQ and DDRP rich in phenolic compounds decreases the formation of secondary products of lipid oxidation and can be used successfully for manufacturing of functional meat products with half added nitrites.

\subsection{Microbiological analysis}

The reduction of nitrites by $50 \%$ in sample $\mathrm{C}^{1 / 2}$ was not effective for the microbial growth suppressing (Table 2). The total viable count in sample $\mathrm{C}^{1} / 2$ was $17.5 \%$ higher than in controls C (100\% nitrite addition). No significant difference in the total viable count between controls $\mathrm{C}$ and sausages from other four samples D1 and D2 or R1 and R2. In comparison to sample $\mathrm{C}^{1 / 2}$ yeast and mold growth was suppressed in samples D1 and R1. Our data are in accordance with the results presented by Khan et al. (2011) about the beneficial effect of bioactive compounds and probiotics added as feed supplement or in filling mass on the shelf life of functional sausages. Many herbs and spices like black pepper, clove, oregano, thyme, (Dalle Zotte, 2016) cinnamon, onion, and garlic (Kreig, 2013) inhibit the microbial growth due to their essential oils content. The strong antimicrobial activity of rosemary was established due to the high level of phenolic antioxidants (Cardinali et al., 2015). DHQ and DDRP as phytonutrients rich in phenolic compounds have strong antioxidant activity too (Shikov et al., 2012; Artem'eva et al., 2015).

The enrichment of the pigs' feed with dihydroquercetin (3.5 or $7.5 \mathrm{~g} / \mathrm{kg}$ live weight $/ \mathrm{d}$ ) or dry distilled rose petals $(0.252$ or $0.545 \mathrm{~g} / \mathrm{kg}$ live weight/d) inhibits the microbial growth in processed sausages during seven-day period of refrigerated storage $\left(0 \pm 4^{\circ} \mathrm{C}\right)$. The lower concentrations of phytonutrients as feed supplement $(3.5 \mathrm{mg} / \mathrm{kg}$ DHQ or $0.252 \mathrm{~g} / \mathrm{kg}$ DDRP live weight/d) had better impact for yeasts and moulds suppressing (Table 2).

\subsection{Dynamics of the colour characteristics during 60 min exposure under air conditions \\ After $60 \mathrm{~min}$ of air exposure the most stable was color lightness $\mathrm{L}^{*}$ in $\mathrm{C}$ and $\mathrm{C}^{1 / 2}$ followed by samples D2 and R1 (Table 3 ).}


Table 3. Changes of colour lightness $\left(\mathrm{L}^{*}\right)$, redness $\left(\mathrm{a}^{*}\right)$ and yellowness $\left(\mathrm{b}^{*}\right)$ in dynamics during the 60 minutes air exposure of sausages cut surface sectional views

\begin{tabular}{|c|c|c|c|c|c|c|c|}
\hline \multicolumn{8}{|c|}{ L*value } \\
\hline $\begin{array}{l}\text { Time, } \\
\text { min }\end{array}$ & $\mathbf{0}$ & 10 & 20 & 30 & 40 & 50 & 60 \\
\hline $\mathbf{C}$ & $59,57^{\mathrm{c}, \mathrm{v}} \pm 0,04$ & $59,28^{\mathrm{b}, \mathrm{w}} 0,05$ & $59,31^{\text {b,y }} \pm 0,09$ & $59,30^{\mathrm{b}, \mathrm{y}} \pm 0,04$ & $59,30^{\mathrm{b}, \mathrm{x}} \pm 0,03$ & $59,28^{\mathrm{b}, \mathrm{x}} \pm 0,04$ & $59,16^{\mathrm{a}, \mathrm{x}} \pm 0,03$ \\
\hline $\mathrm{C}^{1 / 2}$ & $58,97^{\mathrm{c}, \mathrm{w}} \pm 0,06$ & $58,96^{\mathrm{c}, \mathrm{y}} \pm 0,01$ & $58,96^{\mathrm{c}, \mathrm{x}} \pm 0,01$ & $58,94^{\mathrm{c}, \mathrm{x}} \pm 0,05$ & $58,74^{\mathrm{b}, \mathrm{v}} \pm 0,05$ & $58,72^{\text {b,w }} 0,03$ & $58,52^{\mathrm{a}, \mathrm{v}} \pm 0,07$ \\
\hline D1 & $59,19^{\mathrm{c}, \mathrm{x}} 0,03$ & $59,34^{\mathrm{c}, \mathrm{x}} \pm 0,30$ & $59,00^{\mathrm{b}, \mathrm{x}} \pm 0,07$ & $58,94^{\mathrm{b}, \mathrm{a}, \mathrm{x}} \pm 0,17$ & $58,90^{\mathrm{b}, \mathrm{w}} 0,04$ & $58,75^{\mathrm{a}, \mathrm{w}} \pm 0,05$ & $58,78^{\mathrm{a}, \mathrm{w}} \pm 0,08$ \\
\hline D2 & $61,12^{\mathrm{a}, \mathrm{z}} \pm 0,04$ & $61,62^{\mathrm{d}, \mathrm{z}} \pm 0,04$ & $61,62^{\mathrm{d}, \mathrm{z}} \pm 0,04$ & $60,77^{\mathrm{a}, \mathrm{z}} \pm 0,61$ & $61,46^{\mathrm{c}, \mathrm{z}} \pm 0,04$ & $61,45^{\mathrm{c}, \mathrm{z}} \pm 0,06$ & $61,30^{\mathrm{b}, \mathrm{y}} \pm 0,03$ \\
\hline R1 & $60,74^{\text {a,y }} 0,12$ & $61,05^{\mathrm{b}, \mathrm{z}} \pm 0,16$ & $61,05^{\mathrm{b}, \mathrm{z}} \pm 0,06$ & $61,28^{\mathrm{c}, \mathrm{z}} \pm 0,09$ & $60,80^{\mathrm{a}, \mathrm{y}} \pm 0,03$ & $60,73^{\mathrm{a}, \mathrm{y}} \pm 0,06$ & $60,79^{\mathrm{a}, \mathrm{z}} \pm 0,08$ \\
\hline R2 & $58,43^{\text {b,c,v }} 0,12$ & $58,48^{\mathrm{d}, \mathrm{v}} \pm 0,01$ & $58,48^{\mathrm{a}, \mathrm{w}} \pm 0,02$ & $58,46^{\mathrm{a}, \mathrm{w}} \pm 0,02$ & $58,27^{\mathrm{b}, \mathrm{u}} \pm 0,08$ & $58,37^{\mathrm{c}, \mathrm{v}} \pm 0,03$ & $58,13^{\mathrm{a}, \mathrm{u}} \pm 0,02$ \\
\hline \multicolumn{8}{|c|}{$a^{*}$ value } \\
\hline $\mathbf{C}$ & $1,76^{\mathrm{g}, \mathrm{x}} \pm 0,03$ & $10,91^{\mathrm{f}, \mathrm{w}} \pm 0,02$ & $10,27^{\mathrm{e}, \mathrm{x}} \pm 0,02$ & $9,76^{\mathrm{d}, \mathrm{x}} \pm 0,03$ & $9,39^{\mathrm{c}, \mathrm{x}} \pm 0,02$ & $9,08^{\mathrm{b}, \mathrm{x}} \pm 0,02$ & $8,86^{\mathrm{a}, \mathrm{x}} \pm 0,01$ \\
\hline $\mathbf{C}^{1 / 2}$ & $2,70^{\mathrm{g}, \mathrm{z}} \pm 0,59$ & $11,27^{\mathrm{f}, \mathrm{x}} \pm 0,01$ & $10,60^{\mathrm{e}, \mathrm{x}} \pm 0,02$ & $10,05^{\mathrm{d}, \mathrm{x}} \pm 0,03$ & $7,93^{\mathrm{a}, \mathrm{x}} \pm 0,02$ & $9,43^{\mathrm{c}, \mathrm{x}} \pm 0,01$ & $9,21^{\mathrm{b}, \mathrm{x}} \pm 0,01$ \\
\hline D1 & $2,39^{\mathrm{g}, \mathrm{y}} \pm 0,04$ & $11,55^{\mathrm{f}, \mathrm{y}} \pm 0,07$ & $10,77^{\mathrm{e}, \mathrm{x}} \pm 0,03$ & $10,19^{\mathrm{d}, \mathrm{x}} \pm 0,05$ & $9,71^{\mathrm{c}, \mathrm{x}} \pm 0,01$ & $9,39^{\mathrm{b}, \mathrm{x}} \pm 0,04$ & $9,18^{\mathrm{a}, \mathrm{x}} \pm 0,02$ \\
\hline D2 & $1,22^{\mathrm{f}, \mathrm{w}} \pm 0,01$ & $10,41^{\mathrm{e}, \mathrm{u}} \pm 0,01$ & $9,72^{\mathrm{d}, \mathrm{x}} \pm 0,02$ & $9,90^{\mathrm{d}, \mathrm{x}} \pm 0,58$ & $8,85^{\mathrm{c}, \mathrm{x}} \pm 0,02$ & $8,58^{\mathrm{b}, \mathrm{x}} \pm 0,02$ & $8,48^{\mathrm{a}, \mathrm{x}} \pm 0,01$ \\
\hline R1 & $1,25^{\mathrm{g}, \mathrm{w}} \pm 0,06$ & $10,50^{\mathrm{f}, \mathrm{v}} \pm 0,05$ & $9,76^{\mathrm{e}, \mathrm{x}} \pm 0,01$ & $9,22^{\mathrm{d}, \mathrm{x}} \pm 0,01$ & $8,82^{\mathrm{c}, \mathrm{x}} \pm 0,01$ & $8,58^{\mathrm{b}, \mathrm{x}} \pm 0,03$ & $8,41^{\mathrm{a}, \mathrm{x}} \pm 0,01$ \\
\hline R2 & $2,80^{\mathrm{g}, \mathrm{z}} \pm 0,02$ & $11,87^{\mathrm{f}, \mathrm{z}} \pm 0,05$ & $11,08^{\mathrm{e}, \mathrm{x}} \pm 0,05$ & $10,48^{\mathrm{d}, \mathrm{x}} \pm 0,01$ & $10,07^{\mathrm{c}, \mathrm{x}} \pm 0,02$ & $9,78^{b, x} \pm 0,03$ & $9,57^{\mathrm{a}, \mathrm{x}} \pm 0,01$ \\
\hline \multicolumn{8}{|c|}{ b* value } \\
\hline $\mathrm{C}$ & $6,72^{\mathrm{a}, \mathrm{y}} \pm 0,06$ & $7,52^{\text {b,y }} \pm 0,02$ & $7,73^{\mathrm{c}, \mathrm{y}} \pm 0,02$ & $8,14^{\mathrm{d}, \mathrm{z}} \pm 0,02$ & $8,30^{\mathrm{e}, \mathrm{y}} \pm 0,01$ & $8,49^{\mathrm{f,y}} \pm 0,03$ & $8,66^{\mathrm{g}, \mathrm{x}} \pm 0,01$ \\
\hline $\mathrm{C}^{1 / 2}$ & $5,32^{\mathrm{a}, \mathrm{v}} \pm 0,05$ & $7,18^{\mathrm{b}, \mathrm{x}} \pm 0,01$ & $7,51^{\mathrm{c}, \mathrm{v}} \pm 0,01$ & $7,81^{\mathrm{d}, \mathrm{y}} \pm 0,01$ & $8,03^{\mathrm{e}, \mathrm{v}} \pm 0,01$ & $8,19^{\mathrm{f}, \mathrm{v}} \pm 0,01$ & $8,34^{\mathrm{g}, \mathrm{w}} \pm 0,02$ \\
\hline D1 & $5,77^{\mathrm{a}, \mathrm{w}} \pm 0,04$ & $6,77^{\mathrm{b}, \mathrm{v}} \pm 0,01$ & $7,15^{\mathrm{c}, \mathrm{u}} \pm 0,05$ & $7,43^{\mathrm{d}, \mathrm{x}} \pm 0,02$ & $7,65^{\mathrm{e}, \mathrm{u}} \pm 0,02$ & $7,84^{\mathrm{f}, \mathrm{u}} \pm 0,01$ & $7,96^{\mathrm{g}, \mathrm{v}} \pm 0,02$ \\
\hline D2 & $6,98^{\mathrm{a}, \mathrm{z}} \pm 0,01$ & $7,64^{\mathrm{b}, \mathrm{z}} \pm 0,01$ & $8,04^{\mathrm{c}, \mathrm{z}} \pm 0,01$ & $8,03^{\mathrm{c}, \mathrm{y}, \mathrm{z}} \pm 0,52$ & $8,56^{\mathrm{c}, \mathrm{z}} \pm 0,02$ & $8,79^{\mathrm{d}, \mathrm{z}} \pm 0,03$ & $8,90^{\mathrm{d}, \mathrm{z}} \pm 0,02$ \\
\hline R1 & $6,17^{\mathrm{a}, \mathrm{x}} \pm 0,02$ & $7,06^{\mathrm{b}, \mathrm{w}} \pm 0,01$ & $7,55^{\mathrm{c}, \mathrm{w}} \pm 0,01$ & $7,99^{\mathrm{d}, \mathrm{y}, \mathrm{z}} \pm 0,29$ & $8,07^{\mathrm{d}, \mathrm{w}} \pm 0,02$ & $8,24^{\mathrm{e}, \mathrm{w}} \pm 0,03$ & $8,35^{\mathrm{f}, \mathrm{w}} \pm 0,02$ \\
\hline R2 & $6,18^{\mathrm{a}, \mathrm{x}} \pm 0,12$ & $7,09^{\mathrm{b}, \mathrm{w}} \pm 0,02$ & $7,61^{\mathrm{c}, \mathrm{x}} \pm 0,02$ & $7,95^{\mathrm{d}, \mathrm{y}} \pm 0,01$ & $8,21^{\mathrm{e}, \mathrm{x}} \pm 0,03$ & $8,42^{\mathrm{f}, \mathrm{x}} \pm 0,02$ & $8,58^{\mathrm{g}, \mathrm{y}} \pm 0,01$ \\
\hline
\end{tabular}

SEM- standard error of the mean.

For the mentioned four samples $\left(\mathrm{C}, \mathrm{C}^{1} \frac{1}{2}\right.$, $\mathrm{D} 2, \mathrm{R} 1)$ the first $\mathrm{L}^{*}$ value $(0 \mathrm{~min})$ and the last $\mathrm{L}^{*}$ value $(60 \mathrm{~min})$ do not differ significantly $(\mathrm{p}$ $>0.05)$. The other two samples D1 and R2 show different trends. In sausages from sample R2 the color lightness $\mathrm{L}^{*}$ significantly decreased by $33.7 \%(\mathrm{p}<0.05)$ for 60 min while in sample D1 L* value slightly increased.

The sausages from sample D1 are the only samples with color lightness increasing after a 60 minute of air exposure (Table 3). The cut surface redness $a^{*}$ traced after $60 \mathrm{~min}$ of air exposure decreased in all tested sausages but most significantly with $37.90 \%(\mathrm{p}<0.05)$ was the decrease in sample $\mathrm{C}^{1} / 2$ (Table 2).

More stable was the $\mathrm{a}^{*}$ value after $60 \mathrm{~min}$ of air exposure in samples D2, R1 and R2 with a decrease of $32.30 \%, 33.7 \%$ and $33.75 \%(p<$ $0.05)$ respectively. Similar changes were found in the colour yellowness $b^{*}$ studied in dynamics.
Once again the most significant decrease was established after $60 \mathrm{~min}$ of air exposure in the controls with half added nitrites - C $1 / 2$. The supplement with DHQ and DDRP in pigs' diet stabilized the $a^{*}$ and $b^{*}$ values of the manufactured sausages with half added nitrites. Our results show that after a feed enrichment with DHQ or DDRP the meat is suitable for processing the sausages with half nitrites addition and ensures stable colour $\left(\mathrm{L}^{*}, \mathrm{a}^{*}, \mathrm{~b}^{*}\right)$ characteristics (Table 3).

\section{Conclusions}

The use of pork supplemented with $3.5 \mathrm{mg}$ or dihydroquercetin and $0.255 \mathrm{~g}$ dried distilled rose petals (Rosa damascene Mill.)/kg live weight/d improves sensory acceptance of produced sausages with half nitrites addition. The higher daily doses phytonutrients, namely 7.5 DHQ $\mathrm{mg}$ or $0.545 \mathrm{~g}$ DDRP/kg live weight/d increased the $\mathrm{pH}$ of the manufactured sausages. Our results show that after feed 
enrichment with DHQ or DDRP the meat is suitable for sausages processing with half nitrites addition with stable colour ( $\left.\mathrm{L}^{*}, \mathrm{a}^{*}, \mathrm{~b}^{*}\right)$ characteristics. Pigs' feed enrichment with DHQ or DDRP decreased the formation of secondary products of lipid oxidation and increased the shelf life of the manufactured cooked sausages with half added nitrites and can be used successfully for development new functional cooked sausages.

\section{References}

Arihara, K. (2006). Strategies for designing novel functional meat products. Meat Science, 74(1), 219-229.

Artem'eva, O. A., Pereselkova, D.A., Fomichev, Yu.P. (2015), Dihydroquercetin, the bioactive substance, to be used against pathogenic mickroorganisms as an alternative to antibiotics. Agricultural Biology, 50(4), 513-519.

Balev, D., Vlahova-Vangelova, D., Mihalev, K., Shikov, V., Dragoev, S., Nikolov, V. (2015). Application of natural dietary antioxidants in broiler feeds, Journal of Mountain Agriculture on the Balkans, 18(2), 224-232.

Botsoglou, N.A., Fletouris, D.J., Papageorgiou, G.E., Vassilopoulos, V.N., Mantis, A.J., Trakatellis, A.G. (1994). Rapid, sensitive, and specific thiobarbituric acid method for measuring lipid peroxidation in animal tissue, food, and feedstuff samples. Journal of Agriculture and Food Chemistry, 42(9), 1931-1937.

Cardinali, R., Cullere, M., Dal Bosco, A., Mugnai, C., Ruggeri, S., Mattioli, S., Castellini, C., Trabalza Marinucci, M., Dalle Zotte, A. (2015). Oregano, rosemary and Vitamin E dietary supplementation in growing rabbits: effect on growth performance, carcass traits, bone development and meat chemical composition. Livestock Science, 175(5), 8389.

Christaki, E., Karatzia, M., Florou-Paneri, P. (2010). The use of algae in animal nutrition. Journal of Hellenic Veterinary Medical Society, 61(3), 267-276.
Council Regulation (EC) No $1 / 2005$ of 22 December 2004 on the protection of animals during transport and related operations and amending Directives 64/432/EEC and 93/119/EC and Regulation (EC) No 1255/97. Official Journal, L 3, 5.1.2005, pp. 1-44.

Dalle Zotte, A., Celia, C., Szendrö, Z. (2016). Herbs and spices inclusion as feedstuff or additive in growing rabbit diets and as additive in rabbit meat: A review. Livestock Science, 189(7), 82-90.

Gelabert, J., Gou, P., Guerrero, L., Arnau, J. (2003). Effect of sodium chloride replacement on some characteristics of fermented sausages. Meat Science, 65(2), 833-839.

Hunt, M.C., King, A. (2012). AMSA Meat Color Measurement Guidelines (pp. 1-135). American Meat Science Association, Champaign, Illinois, USA.

ISO 4833:2003. Microbiology of food and animal feeding stuffs. Horizontal method for the enumeration of microorganismscolony-count technique at $30^{\circ} \mathrm{C}$.

Jerónimo, E., Alves, S. P., Prates, J.A., SantosSilva, J., Bessa, R. J. (2009). Effect of dietary replacement of sunflower oil with linseed oil on intramuscular fatty acids of lamb meat. Meat Science, 83(3), 499-505.

Jiang, J. and Xiong, Y. L. (2016). Natural antioxidants as food and feed additives to promote health benefits and quality of meat products: A review. Meat Science, 120(10), 107-117.

Karwowska, M., Dolatowski, Z. J. (2013). Antioxidant effects of ground mustard seed in model sausage type product. Food Science and Technology Research, 19(1), 23-28.

Khan, M.I., Arshad, M.S., Anjum, F.M., Sameen, A., Gill, W.T. (2011). Meat as a functional food with special reference to probiotic sausages. Food Research International, 44(10), 3125-3133.

Kumar, Y., Yadav, D.N., Ahmad, T., Narsaiah, K. (2015). Recent trends in the use of natural antioxidants for meat and meat 
products. Comprehensive Reviews in Food Science and Food Safety, 14(6), 796-812.

Lopez-Ferrer, S., Baucells, M.D., Barroeta, A.C., Grashorn, M.A. (2001). n-3 Enrichment of chicken meat. 1. Use of very long-chain fatty acids in chicken diets and their influence on meat quality. Fish oil. Poultry Science, 80(6), 741-752.

Meilgaard, M.C., Civille, G.C., Carr, B.T. (1987). Sensory Evaluation Techniques.Volume II. CRC Press, Boca Raton, FL, USA. pp. 176.

Nieto, G., Díaz, P., Bañón, S., Garrido, M. D. (2010). Dietary administration of ewe diets with a distillate from rosemary leaves (Rosmarinus officinalis L.): Influence on lamb meat quality. Meat Science, 84(1), 2329.

SAS Institute Inc. 1990. SAS ${ }^{\circledR}$ Procedures Guide, Version 6, Third Edition, Cary, NC: SAS Institute Inc.

Salejda, A.M., Nawirska-Olszańska, A., Janiewicz, U., and Krasnowska, G., (2017). Effects on Quality Properties of Pork Sausages Enriched with Sea Buckthorn (Hippophae rhamnoides L.). Journal of Food Quality, Article ID 7123960 , 7 pages, 2017. https://doi.org/10.1155/2017/712396 0 .

Shikov, V., Kammerer, D. R., Mihalev, K., Mollov, P., Carle, R. (2012). Heat stability of strawberry anthocyanins in model solutions containing natural copigments extracted from rose (Rosa damascena Mill.) petals. Journal of Agricultural and Food Chemistry, 56(18), 8521-8526.

Sobolev, A., Gutyj, B., Grynevych, N., Bilkevych V., Mashkin, Y. (2017). Enrichment of meat products with selenium by its introduction to mixed feed compounds for birds. Regulatory Mechanisms in Biosystems, 8(3), 417-422.

Terpstra, A.H.M., Beynen, A.C., Everts, H., Kocsis, S., Katan, M.B., Zock, P.L. (2002). The decrease in body fat inmice fed conjugated linoleic acid is due to increases in energy expenditure and energy loss in the excreta. Journal of Nutrition. 132(5), 940945.

Ventanas, S., Ventanas, J., Tovar, J., García, C., Estévez, M. (2007). Extensive feeding versus oleic acid and tocopherol enriched mixed diets for the production of Iberian dry-cured hams: Effect on chemical composition, oxidative status and sensory traits. Meat Science, 77(2), 246-256.

Vlahova-Vangelova, D., Balev, D., Dragoev, S., Kapitanski, B., Mihalev, K., Doncheva, T. (2014). Influence of goji berry, pumpkin powder and rose petal extract on the quality of cooked sausages with reduced nitrite content. In: Proceedings of the 2nd International Congress, "Food Technology, Quality and Safety" (pp.1-6). Novi Sad, Serbia.

Wiklund, E., Pickova, J., Sampels, S., Lundström, K. (2001). Fatty acid composition of m. Longissimus lumborum, ultimate muscle $\mathrm{pH}$ values and carcass parameters in reindeer (Rangifer tarandus tarandus $L$ ) grazed on natural pasture or fed a commercial feed mixture. Meat Science, 58(3), 293-298.

Young, O. A., West, J., Hart, A.L., van Otterdijk, F.F.H. (2004). A method for early determination of meat ultimate $\mathrm{pH}$. Meat Science, 66(2), 493-498.

\section{Acknowledgement}

The authors gratefully acknowledge financial support from the National Research Program "Young Scientists and Postdocs". 